\title{
Impact of novel coronavirus (COVID-19) on daily routines and air environment: evidence from Turkey
}

\author{
Hussain Ali $^{1} \cdot$ Gozde Yilmaz $^{1} \cdot$ Zeeshan Fareed $^{2} \cdot$ Farrukh Shahzad $^{3}$ (D) Munir Ahmad $^{4}$ \\ Received: 2 June 2020 / Accepted: 13 September 2020 / Published online: 22 September 2020 \\ (C) Springer Nature B.V. 2020
}

\begin{abstract}
Turkish people are facing several problems because of the novel coronavirus (COVID-19), as the pandemic has brought about drastic changes to their daily routines. This study mainly investigates the impact of this pandemic on the daily routines of Turkish. It also unveils how COVID-19 affects the air environment. The adopted methods for data collection are based on open-ended questions and Facebook interviews as per recommended by QSR-International (2012). The sample of this study comprises of Turkish students as well as professional workers. The findings of the research show that there are eighteen different results of COVID-19 that have been identified according to the Turkish people's daily routines. Results reveal that increasing unemployment, decrease in air contamination, high stress and depression, a slowdown in the economic growth, and the tourism industry are profoundly affected due to the COVID-19 in Turkey. Furthermore, on the one hand, the consequences of the pandemic are segregated into social problems and psychological issues in daily routines. On the other hand, they have shown a positive impact on the air environment. This study concludes that, amid the COVID-19 pandemic, the lives of the people in Turkey are subject to deterioration, while the air environment of Turkey is gradually improving.
\end{abstract}

Keywords COVID-19 · Daily Routines $\cdot$ Air Environment $\cdot$ Social Problems $\cdot$ Psychological Problems

\section{Introduction}

The COVID-19 pandemic disease was confirmed in Turkey on March 11, 2020, when a Turkish person came back from Europe, and his coronavirus test was positive (Sabah 2020a). The Turkish government announced publicly on 12 March 2020 that the primary, middle, and high schools would remain closed for 1 week and the universities for 3 weeks. Yekta Sarac, president of the Council of Higher Education, declared on 26 March 2020 that all universities continue the spring semester through remote education. He also explains

Electronic supplementary material The online version of this article (https://doi.org/10.1007/s11869-020-00943-2) contains supplementary material, which is available to authorized users.

Farrukh Shahzad

farrukh.hailian@gmail.com

Graduate School of Social Sciences, Isik University, Istanbul, Turkey

2 School of Business, Huzhou University, Huzhou, Zhejiang, China

3 School of Economics and Management, Guangdong University of Petrochemical Technology, Maoming, Guangdong, China

4 School of Economics, Zhejiang University, Hangzhou, China that practical courses could not be offered with a distance learning system, and at the end of the summer months, digital education would be completed (sputniknews 2020). High school entrance exam (LGS) will be conducted on 20 June, and the higher education exam (YKS) will be held on 27-28 June, as decided by President Recep Tayyip Erdogan on 5 May 2020 (Agency 2020a). In Turkey, because of COVID19, first death occurred on 15 March 2020, and novel coronavirus had widely spread in Turkey until 1 April 2020 (Euronews 2020). The second death due to COVID-19 was a 61-year-old male patient, as reported by Minister Koca on 18 March 2020. After that, there was a rapid increase in recent cases and the number of total cases has risen to 191 (Hurriyet 2020a). On 12 April 2020, COVID-19 reached the peak in its fourth week, and after that, it slowed down as declared by the head of Turkish Head Minister Fahrettin Koca (Agency 2020b). The Ministry of Interior observed the first curfew on 21 March for those whose age was over 65 or chronically ill (Kandemir 2020). Minister Koca imposed the second curfew on 3 April for the younger than 20 years old, and the wearing of masks became mandatory in public places (Turk 2020). Directorate of Religious Affairs announced on 14 March that for COVID-19 pandemic mosques would be closed for offering prayer, including Friday prayers (Sabah 2020b). The 
Ministry of Interior sent a notice on 15 March regarding COVID-19 precautions to 81 provinces for closing public gatherings such as movie theaters, gyms, and cafes, except for shops and restaurants which are not offering music (Hurriyet 2020b). Like other countries, COVID-19 affected the Turkish economy because the Turkish supply chain faced adverse effects; it declined between Turkey and China with $1.1 \%, 6.4 \%$ for Germany, $11.1 \%$ for South Korea, and $16.6 \%$ for the USA. Therefore, Turkey faces scarcity in supply chains and this hit the manufacturing sector (SAK 2020). Mustafa Varank, Minister of the Industry and Technology, stated all major automotive industries in the country to resume its operations on 11 May (Go kkoyun 2020).

COVID-19 influences the daily routines of the industrial workers because compact units are closed, large organizations cannot use their full capacity, and tourism and restaurant sectors are severely affected. Now Turkey has many challenges, including unemployment, less inflow of foreign investment, repeated change in government policies, export, and GDP growth also decreased (Acikgoz and Gunay 2020). Due to the outbreak of COVID-19, most of the industries have been closed and mobility considerably reduced, which resulted in mitigation of air pollution from fossil fuel burning in industries and vehicles that lead to a good air environment (Kaskun and Ulutas 2020; Singh and Chauhan 2020). We can say that COVID-19 entails all aspects of life in Turkey.

The goal of this study is to explore the relationship between COVID-19 and people's daily routines and the air environment in Turkey. This paper reveals how COVID-19 influences the daily routines of people regardless of their occupations. First, current research has the nature of qualitative research approaches to discover the implications of COVID-19 for people's daily routines, overall performance, and the air environment.

\section{Literature review}

Turkey keeps away from novel coronavirus (COVID-19) until the first case declared on March 11, 2020. Before this pandemic OECD (Organisation for Economic Co-operatoin and Development), expectation with the Turkish economy, it will decline from $2.7 \%$ to $0.9 \%$ and predicted the negative impact of this pandemic on the Turkish economy if the government did not give more attention to policy measures (OECD 2020). According to the World Bank (2018), with a GDP of $\$ 771$ billion, Turkey has become the 19th largest economy in the world. Turkey's major export destinations are Germany (9\%), UK (6.3\%), Italy (5.4\%), Iraq (5.2\%), and USA (4.7\%). In contrast, the major import intensive countries include Russia $(11.1 \%)$, China $(9.1 \%)$, Germany $(8.9 \%)$, USA $(5.5 \%)$, and Italy (4.2\%) (Institute TTS 2019). Data show that the Turkish government does not depend only on Chinese imports; however, other countries' economies suffering from COVID-19 also harmed Turkey's manufacturing sector. Due to this pandemic, Turkish exports decreased by $17.81 \%$ in March 2020, while its imports improved by $3.13 \%$ likened with March 2019 (Ministry of Trade 2020). The Turkish current account deficit noted \$1.804 million significant improvement of \$1.528 million as compared with January of last year; the entire year rolling surplus was $\$ 6.494$ million (Central Bank Turkey 2020). However, the decline will be expected in 2020 as a result of lower goods trade surplus due to the current pandemic. Since 2018 Turkey has coped with unemployment ratio of $13.7 \%$ (Institute TTS 2020b). The unemployment rate increased rapidly among the blue-collar workers due to closures of factories and workplaces, and this was the first economic loss reported (Acikgoz and Gunay 2020). The tourism sector will be badly damaged, and if COVID-19 does not finish by the end of this summer, Turkey will lose the place of 50 million visitors and $\$ 34.5$ billion income (Institute TTS 2020a). The only positive impact of COVID-19 is the improved air environment, as suggested by recent research (Gautam 2020; Shahzad et al. 2020; Fareed et al. 2020). In this regard, Gautam (2020) denoted that due to COVID-19, global air pollution is significantly reduced and the natural environment gains additional benefits. Additionally, Shahzad et al. (2020) also suggested that due to less transportation and closed manufacturing plants, there are fewer carbon emissions in the air, which improved the air environment as well.

COVID-19 epidemic not only brought the health risk but also create intolerable psychological pressure on Chinese people and all over the world (Xiao 2020; Duan 2020). Due to the continuous spread of COVID-19 epidemic causes delays in starting school, college, and universities in the overall country, and it is expected to affect the mental health of students ( $\mathrm{Li}$ et al. 2020). At the time of the Chinese spring festival, friends and family members' communication increased. The Chinese government strictly prohibited from going to public places due to COVID-19, so family members care for each other and spend time together at the Chinese spring festival. This festival is significant for Chinese people because they celebrate the new year according to the traditional Chinese calendar with the hope that the new year brings for them opportunities and new hope for improvement. Under these circumstances, Chinese people contact each other through WeChat or other social media (Lau et al. 2020). The impact of COVID-19 will be different around the world. For example, the International Labour Organization proclaimed that between 5.3 million and 24.7 million jobs vanished and income loss between $\$ 860$ billion to $\$ 3.4$ trillion by the end of 2020 due to novel coronavirus (Int'l Labour Organization 2020). China's pre-crisis GDP growth was $6 \%$, which is now declined to less than $3 \%$. In contrast, most European countries fall in significant recessions because pre-crisis these countries' GDP growth rate was not expected to grow, so nowadays, their GDP declines up to -2 to $-3 \%$. A decline in GDP 
significantly affects rising unemployment. Suppose we talk about the COVID-19 measures until the end of June 2020. The US GDP is expected to fall by almost 4\%. Italy, Germany, Spain, Portugal, and Germany's GDP growth declined by $-6 \%$ (Nuno 2020). It has been argued that the COVID-19 affects people's social life because of the first restriction on traveling imposed by China and Italy in the face of the fear of the outbreak of coronavirus (Andrea and Giuseppe 2020). Air pollution can dilute the immune system, so people are easily infected from the current pandemic. Rise in air pollution may increase in intensity COVID-19 patients (Croft et al. 2019). Nitrogen dioxide $\left(\mathrm{NO}_{2}\right)$ premier sources are industry and road traffic, which contribute to air pollution. Higher air pollution may increase the death from COVID-19 (Pierangeli et al. 2020).

\section{Conceptual model}

Figure 1 shows the conceptual model. This model illustrates that COVID-19 upsets the daily routines of Turkish people, creating psychological and social problems. This model also indicates that the consequences of COVID-19 reduced people's overall performance in everyday life.

\section{Research methodology}

\section{Nature of research}

The research will base on the interpretivism paradigm, exploratory, and qualitative because the core purpose of this study to discover various significances of COVID-19 on Turkish people's daily routines. In this research, the case study method has been adopted. Moreover, as can be seen in Suppplement, the study sample consists of students $(56 \%)$ and professionals (44\%) who are living in Turkey (Supplement Fig. S1).

\section{Data collection methods}

In this study, data has been collected through two different methods. The first one includes open-ended questions that have been asked by Turkish people for data collection about the consequences of COVID-19. Secondly, the data are collected through written comment-based interviews conducted through Facebook. Interview data has been arranged by employing NVivo 12 "N Capture Option. A Facebook page has been developed for this procedure and sharing on Facebook social group. In a week, 30 people wrote about personal daily routine problems about the nastiest circumstances in Turkey due to COVID-19. The study has employed data from 15 relevant respondents by using NVivo $12 \mathrm{~N}$ Capture Option.

\section{Data analysis methods}

NVivo 12 has been used for qualitative data analysis methods comprising coding of data, cluster analysis, thematic analysis, word cloud, and words frequency analysis. Cluster analysis through similarity code means numerous times investigators have the unique nature of references for code the node. However, themes that have similar coding are close to each other and themes that are at a distance have different coding. NVivo software helps in data organization and its analysis, but it allows the scholars to fuel enough energy for organizing, coding, and analyzing the data (Ozkan 2004).

NVivo Text Analysis characteristics support to understand the themes and search the language in the project. Identify the themes of discovering the people's way of talking about the specific study done by the text search query. There are various graphs that have been used; for example, a treemap is used to define findings and explanations. Text search, word frequency, and metrics coding queries have been implemented to show the serious significances of COVID-19 in the daily routines of Turkish people.

Fig. 1 Conceptual model

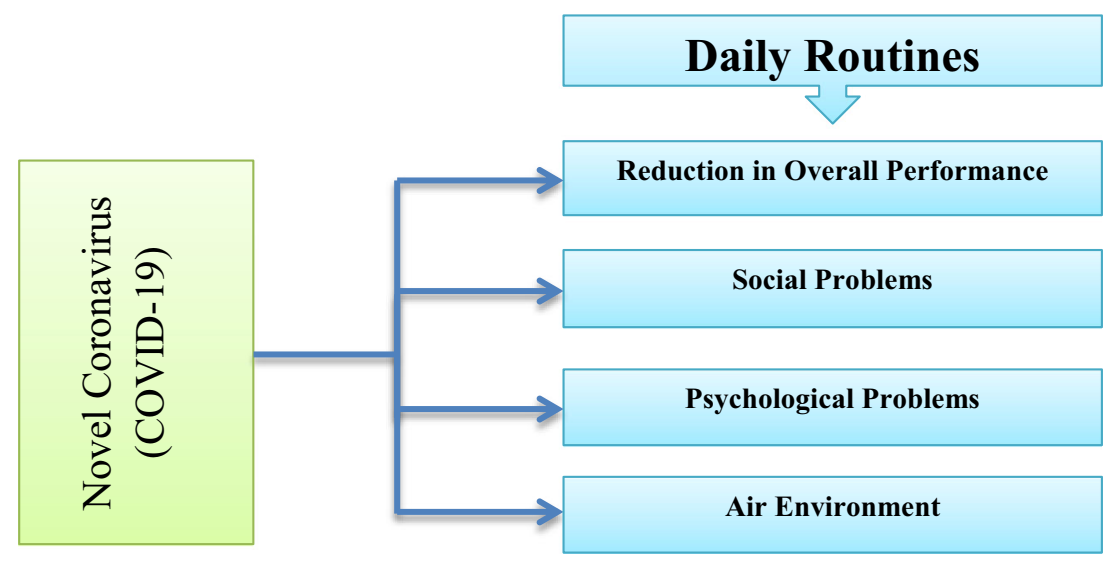


The "word tag cloud" presents numerous themes in different font sizes according to the frequency of recurrence of their words, as can be seen in Supplement (Fig. S2). It is very beneficial for performing thematic analysis because we can recognize a further theme in our research by tag cloud map. Moreover, Supplement Fig. S2 displays different themes related to unemployment, students' online learning, people's depression, tourism, and economy to be badly affected by COVID-19.

As a further step, Figure 2 shows the Word Treemap that illustrates the connections of keyword with the different patterns of talk. In this query, the keyword is "COVID-19." Word Treemap is identifying the relationship between themes.

Figure 3 presents the matrix coding query that shows the demographic groups according to respondent names including, gender, occupation, and ages. Here different rows with different colors indicate the different attributes. The last row about gender (male and female) reflects that the number of male respondents exceeds that of females. The second row concerning the professional occupation reveals that the workers are less than students. Also, the first row shows the age group of respondents. In this respect, the first group of respondents, with age under 21-30 years, are mostly students. The second age group under 31-40 years have professional workers. The third age group 41-50 years has no candidate. However, the last age limit from 51-60 year has only one professional female respondent. Additionally, the respondents in the age group of 21-30 years are more than those in the other age groups.

\section{Result of the study}

\section{Results of novel coronavirus (COVID-19)_“Word Treemap"}

Figure 4 shows the "Word Treemap" used to display the different consequences of novel coronavirus (COVID-19).

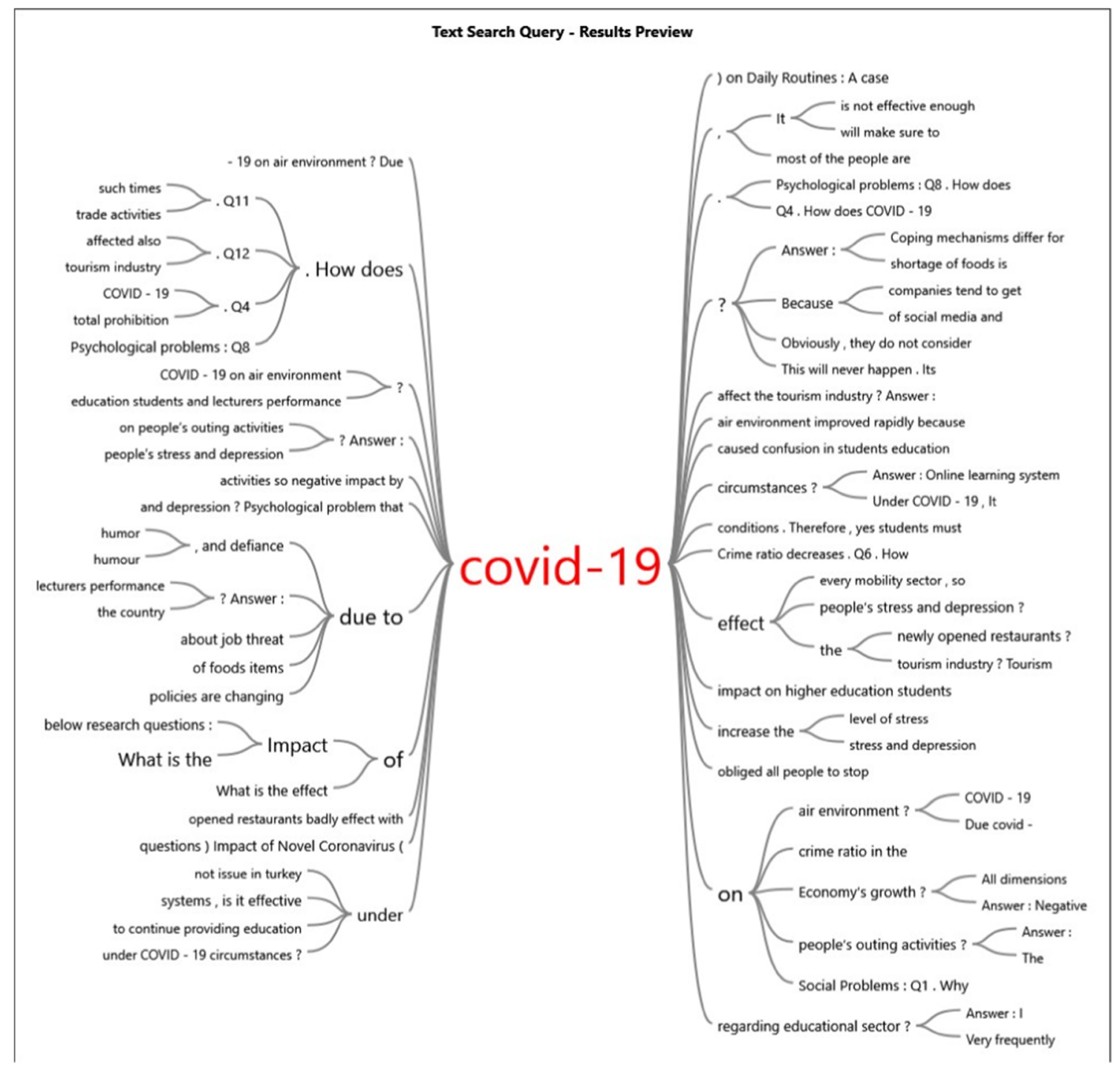

Fig. 2 Word Treemap for COVID-19 


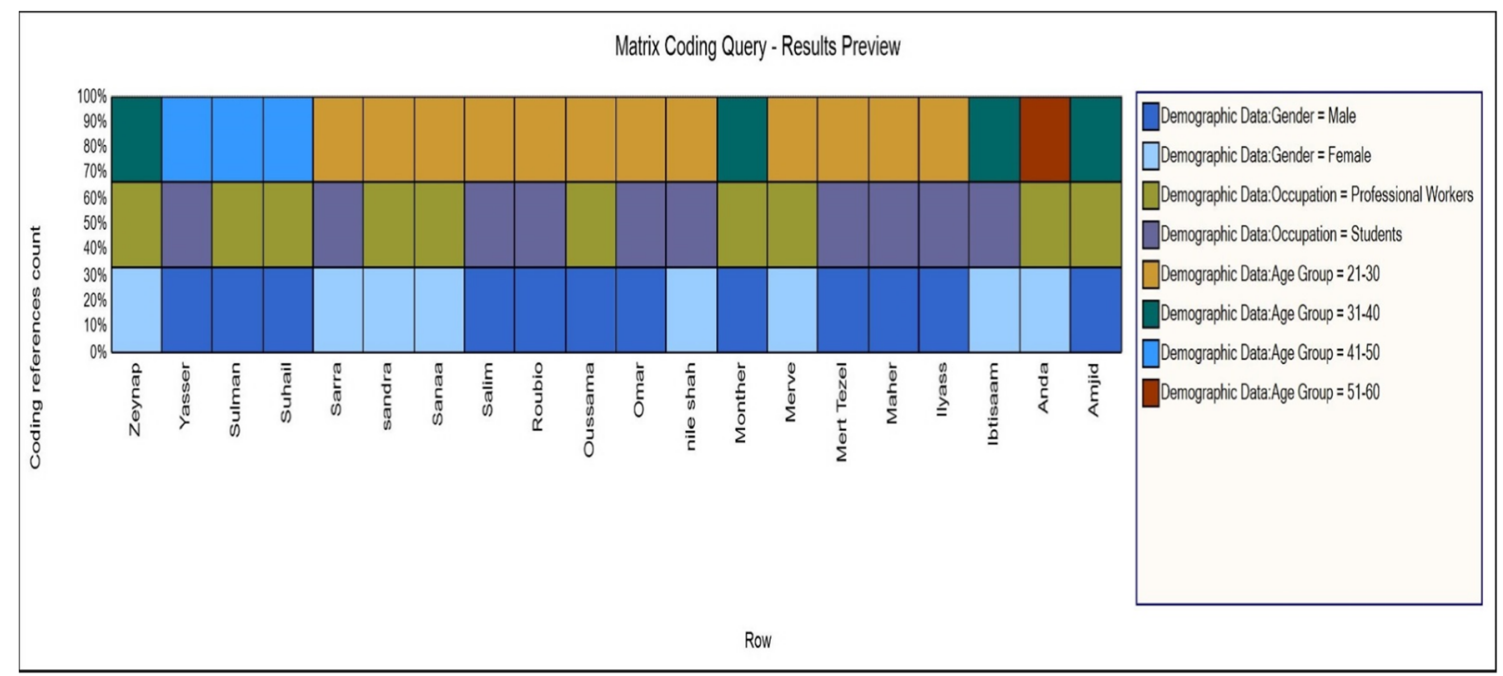

Fig. 3 Matrix coding query

Figure 4 shows that consequences of COVID-19, including unemployment, air environment, loss in the tourism sector, fear and humor, inefficient learning, and closed restaurants, are more perilous as more references to these themes are available as compared with the other results. Though government policies, stress, and depression, economic growth and outdoor activities decreased have been recognized as less dangerous results of COVID-19 (Ahmad et al. 2020). At the same time, higher education performance, crime ratio, and shortage of food have been originated to be less affecting the consequence of COVID-19 because of the lower number of reactions with reference to other results. Ultimately, every type of sector is affected by the present pandemic, which generates unemployment and improves the air environment. Due to the COVID19 , the unemployment ratio has been increased, while the air environment is improved. In Turkey, the tourism and restaurant sector are more critically disturbed, whereas the novel coronavirus less influenced the food industry and education system.
Figure 5 indicates different outcomes of COVID-19, according to respondents. The matrix explains the demographic data of respondents and indicates the respondent's response towards each factor recognized in this research.

\section{Relational Approach to COVID-19 and daily routine problems}

Social and psychological problems occurred in daily routines due to the COVID-19 pandemic. In this study, relationship between them has been explored by respondents' responses. Fear and humor, stress, and depression can be considered psychological problems, but respondent more reactions about stress and depression as compared with fear and humor. Whereas, unemployment threats, COVID-19 have a positive impact on air environment, inefficient educational learning, outdoor activity decrease, inadequate performance of higher education, random government policies, and the shortage of foods are social problems. Loss in tourism, and restaurant

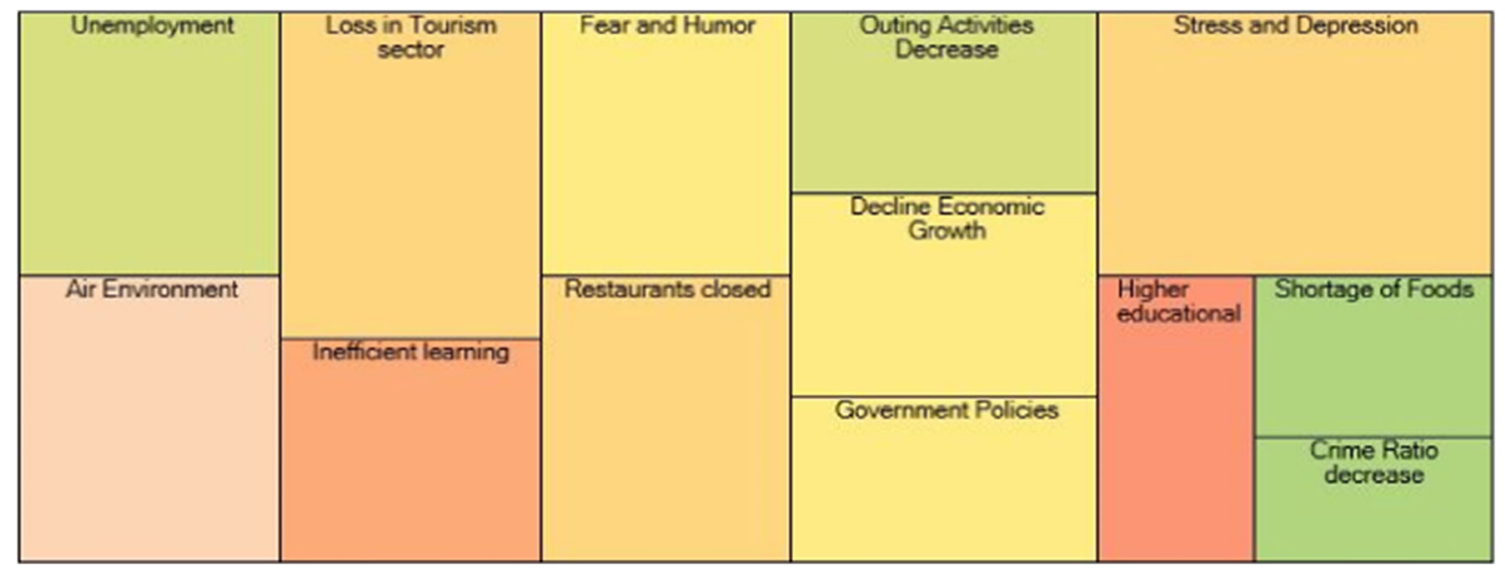

Fig. 4 Tree Map — extent of relationship 


\begin{tabular}{|c|c|c|c|c|c|c|c|c|}
\hline & $\begin{array}{c}\text { A: } \\
\text { Demographic } \\
\text { data: } \\
\text { Gender }= \\
\text { Female }\end{array}$ & $\begin{array}{c}\text { B: } \\
\text { Demographic } \\
\text { data: } \\
\text { Gender }= \\
\text { Male }\end{array}$ & $\begin{array}{c}\text { C: } \\
\text { Demographic } \\
\text { data: } \\
\text { Oocupation = } \\
\text { Student }\end{array}$ & $\begin{array}{c}\text { D: } \\
\text { Demographic } \\
\text { data: } \\
\text { Oocupation = } \\
\text { Professional } \\
\text { worker }\end{array}$ & $\begin{array}{c}\text { E: } \\
\text { Demographic } \\
\text { data: } \\
\text { Age = 21-30 }\end{array}$ & $\begin{array}{c}\text { F: } \\
\text { Demographic } \\
\text { data: } \\
\text { Age }=31-40\end{array}$ & $\begin{array}{c}\text { G: } \\
\text { Demographic } \\
\text { data: } \\
\text { Age }=41-50\end{array}$ & $\begin{array}{c}\text { H: } \\
\text { Demographic } \\
\text { data: } \\
\text { Age }=51-60\end{array}$ \\
\hline 1: Air Environment & 9 & 11 & 8 & 8 & 12 & 4 & 2 & 1 \\
\hline 2: Unemployment & 8 & 10 & 10 & 8 & 13 & 4 & 2 & 1 \\
\hline 3: Fear and Humour & 5 & 9 & 8 & 6 & 9 & 4 & 0 & 1 \\
\hline 4: Stress and Depression & 9 & 10 & 10 & 9 & 14 & 4 & 2 & 1 \\
\hline $\begin{array}{l}5 \text { : Decline Economic } \\
\text { Growth }\end{array}$ & 8 & 8 & 8 & 8 & 11 & 4 & 2 & 1 \\
\hline 6: Restaurants Closed & 8 & 10 & 10 & 8 & 13 & 4 & 1 & 1 \\
\hline $7:$ Loss in Tourism Sector & 8 & 10 & 10 & 8 & 13 & 4 & 0 & 1 \\
\hline 8: Crime Ratio & 7 & 11 & 11 & 7 & 13 & 4 & 0 & 1 \\
\hline 9: Government Policies & 8 & 9 & 9 & 8 & 12 & 4 & 2 & 1 \\
\hline $\begin{array}{l}10 \text { : Higher Education } \\
\text { Performance }\end{array}$ & 8 & 8 & 9 & 7 & 12 & 3 & 2 & 1 \\
\hline 11 : Inefficient Learning & 8 & 10 & 10 & 8 & 13 & 4 & 0 & 1 \\
\hline $\begin{array}{l}12 \text { : Outing Activities } \\
\text { Decrease }\end{array}$ & 8 & 9 & 9 & 8 & 12 & 4 & 1 & 1 \\
\hline 13 : Shortage of foods & 7 & 9 & 10 & 6 & 11 & 4 & 2 & 1 \\
\hline
\end{tabular}

Fig. 5 Respondent-wise results of COVID-19

sector, and inefficient economic growth are some results of COVID-19, which decreases the overall performance in daily routines. The psychological issue is the major problem and leads to many other major health problems as suggested by Cetin et al. (2019)

\section{Conclusion}

This research recognized the results of COVID-19 in the daily routines of Turkish people. Firstly, the study collected data through open-ended questions asked from students and professionals about the outcome of COVID-19. Secondly, data collected through written comment-based interviews conducted by using a social network "Facebook" from Turkish people. Different qualitative data analysis techniques have employed NVivo 12. This study acknowledged the twelve factors on which the result of COVID-19 is based in Turkey.

Based on the results, it concluded that COVID-19 has been changing the lives of Turkish people regardless of their occupations. Everyone, including students, workers, traders, and industrialists, are suffering from the pandemic. Due to the current epidemic, it is hard for Turkey to make progress in any field. There are many post effects of COVID-19 in Turkey like unemployment, ameliorated air environment, inefficient online learning, decrease in outing activities, fear, and depression, and restaurants and the tourism sector are severely affected. The air environment is experiencing improvement during the outbreak of the pandemic, due to the shutdowns of the transport industry as well as other industries. It is further found that the air pollution decreased in Turkey by $11.8 \%$. Due to this, the death rate and the diseases that were previously existent due to air pollution may decline by 10 percent, as suggested by Kaskun and Ulutas (2020). COVID-19 is seriously affecting people's daily routines and the overall economic growth of Turkey as it is gradually becoming a necessary evil. However, because of COVID-19, the air environment is improving not only in Turkey but all over the world. Though this study is limited to Turkey, it may provide a better foundation for future research works to be conducted in other regions around the globe.

\section{References}

Acikgoz O, Gunay A (2020) The early impact of the Covid-19 pandemic on the global and Turkish economy. Turk J Med Sci 50:520-526

Agency A (2020a) Cumhurbaşkanı Erdogan: Normal hayata donusu kademe kademe baslatacagiz. https://www.aa.com.tr/tr/turkiye/ cumhurbaskani-erdogan-normal-hayata-donusu-kademe-kademebaslatacagiz/1828617. Accessed on 15 June 2020

Agency A (2020b) Saglik Bakanı Koca: Turkey'de 4. haftada vaka artıs h1z1 dususe gecti. www.aa.com.tr, Turkey. Accessed on 21 June 2020

Ahmad M, Iram K, Jabeen G (2020) Perception-based influence factors of intention to adopt COVID-19 epidemic prevention in China. Environ Res 190(109995):1-9

Andrea R, Giuseppe R (2020) COVID-19 and Italy: What next? Lancet 395:1225-1228

Cetin M, Adiguzel F, Gungor S, Kaya E, Sancar MC (2019) Evaluation of thermal climatic region areas in terms of building density in urban management and planning for Burdur, Turkey. Air Qual Atmos Health 12(9):1103-1112

Croft D, Rich D, Hopke P, Thevenet-Morrison K, Thurston S, Georas S, Falsey A (2019) Risk of influenza and respiratory syncytial virus infection associated with particulate air pollution: an adult casecontrol study. D26, health effects associated with indoor and outdoor air pollution: American Thoracic Society, (pp. A6020-A6020)

Duan L (2020) Psychological interventions for people affected by the COVID-19 epidemic. Lancet Psychiatry 7:300-302 
Euronews (2020) Saglık Bakanı Koca: Son 24 saatte 7 kisi hayatını kaybetti, 293 yeni vaka goruldu. www.star.com.tr, Turkey. Accessed on 23 March 2020

Fareed Z, Iqbal N, Shahzad F, Shah SGM, Zulfiqar B, Shahzad K, Shahzad U (2020) Co-variance nexus between COVID-19 mortality, humidity, and air quality index in Wuhan, China: New insights from partial and multiple wavelet coherence. Air Qual Atmos Health 13:673-682

Gautam S (2020) COVID-19: air pollution remains low as people stay at home. Air Qual Atmos Health 13:853-857

Go kkoyun SC (2020) 11 Mayıs itibarıyla tüm otomotiv ana fabrikaları faaliyetlerine başlamış olacak. www.haberler.com, Anadolu Ajansı. Accessed on 5 May 2020

Hurriyet (2020a) Son dakika haberleri... Corona virus onlemleri: Kahvehaneler, kafeler, spor salonları kapatılıyor. www.hurriyet. com.tr, Türkiye. Accessed on 16 March 2020

Hurriyet (2020b) Sağlık Bakanı Koca'dan son dakika corona virus acklaması! Corona virus ten ikinci olum. www.hurriyet.com.tr, Türkiye. Accessed on 18 March 2020

Institute TTS (2019) Foreign trade statistics. Ankara, Turkey

Institute TTS (2020a) Tourism statistics, Quarter IV: October-December and Annual, 2019. Anakara, Turkey

Institute TTS (2020b) Press Release: consumer price Index, March 2020. Ankara, Turkey

Kandemir A (2020) Turkey imposing curfew for people over Age 65. www.bloomberg.com. Accessed on 21 March

Kaskun S, Ulutas K (2020) The effect of COVID-19 pandemic on air quality caused by traffic in Istanbul. Research square, 1-24

Lau JT, Yang X, Tsui H, Kin JH (2020) Monitoring community responses to the sars epidemic in hong kong. J Epidemiol Community Health 57:864-870

Li Q, Guan X, Peng W (2020) Early transmission dynamics in Wuhan, China, of novel coronavirus-infected pneumonia. New Engl J Med 382:1199-1207

Nuno F (2020) Economic effects of coronavirus outbreek (COVID-19) on the world economy. http://www.oecd.org/economy/globaleconomy-faces-gravest-threatsince-the-crisis-as-coronavirusspreads.htm., 22 March: 22-24. Accessed on 12 June 2020

OECD (2020) OECD interim economic assessment coronavirus: the world economy at risk. Paris, France: Organisation for Economic Co-operatoin and Development. 2 March 2020

Organization ILO (2020) COVID-19 and the world of work: impact and policy responses. ILO Monitor 1st ed. 18 March, Geneva, Swtizerland
Ozkan BC (2004) Using NVivo to analyze qualitative classroom data on constructivist learning environment. Qual Rep 9(4):589-603

Pierangeli I, Nieuwenhuijsen M, Cirach M, Rojas-Rueda D (2020) Health equity and burden of childhood asthma-related to air pollution in Barcelona. Environ Res 186:109067

Sabah D ( 2020a) Turkey confirms first coronavirus patient, recently returned from Europe. www.dailysabah.com, Turkey. 11 March. Accessed on 10 June 2020

Sabah D (2020b) Turkey's Diyanet bans prayer gatherings, Friday prayers in mosques due to coronavirus. www.dailysabah.com, Turkey. 16 March. Accessed on 23 June 2020

Sak G (2020) Just how bad is COVID-19 for Turkey's economy? March 13. www.hurriyetdailynews.com, Turkey. Accessed on 5 June 2020

Shahzad F, Shahzad U, Fareed Z, Iqbal N, Hashmi SH, Ahmad F (2020) Asymmetric nexus between temperature and COVID-19 in the top ten affected provinces of China: A current application of quantileon-quantile approach. Sci Total Environ 139115

Singh RP, Chauhan A (2020) Impact of lockdown on air quality in India during COVID-19 pandemic. Air Qual Atmos Health 13:921-928

Sputniknews (2020) YOK President: There will be no face-to-face training at universities during the spring semester, YKS has been postponed to 25-26 July. Sputniknews, Turkey

Trade ROTMO (2020) Foreign Trade, Craftsman and Cooperative Data of March, 2020. Ankara, Turkey

Turk C (2020) Son dakika... Cumhurbaşkanı Erdoğan yeni tedbirleri açıkladı! 20 yas altına sokaga cıkma yasagı. 3 April. www. cnnturk.com, Turkiye. Accessed on 13 June 2020

Turkey CBOTRO (2020) Balance of Payments Statistics January,. Ankara, Turkey. https://www.tcmb.gov.tr/wps/wcm/connect/en/ $\mathrm{tcmb}+\mathrm{en} / \mathrm{main}+\mathrm{menu} / \mathrm{statistics/balance+of+payments+and+}$ related+statistics/balance+of+payments+statisticss. Accessed on 14 June 2020

World Bank (2018) Economic develompment indicator of Turkey final review. https://www.worldbank.org/en/news/opinion/2018/06/26. Accessed 1 August 2018

Xiao C (2020) A Novel Approach of Consultation on 2019 Novel Coronavirus (COVID-19)-Related Psychological and Mental Problems: Structured Letter Therapy. Psychiatry Investig 17(2): 175-176. https://doi.org/10.30773/pi.2020.0047

Publisher's note Springer Nature remains neutral with regard to jurisdictional claims in published maps and institutional affiliations. 